\title{
EDUCATION FOR ENTREPRENEURSHIP IN SERBIAN ACADEMIC ENVIRONMENT: CHALLENGES FOR LIBRARIES
}

\author{
Vesna Župan ${ }^{318}$ \\ https://doi.org/10.31410/itema.2018.930
}

\begin{abstract}
Profit oriented economy needs experts who would be able to contribute to the development. Learning for entrepreneurship is senseless if adequate plans and programmes were not previously created in order to educate students for the Entrepreneurial Age. An academic librarianship should follow contemporary tendencies in the world economy and tend to meet its users expectations. Students are the most numerous among them.

This paper concentrates on the problems and collections of Serbian academic librarianship with the aim to show how much contemporary economic thought is being followed for the needs of users. It is had in mind that the economic thought makes strong influence on creating knowledge of future entrepreneurs. The theoretical framework of this paper is a libraryinformation one. The method used in it is of an empirical-statistical nature.

The subject cataloguing and classification of the economic materials are being realized under more favorable technical conditions than earlier when we talk on the academic librarianship of Serbia. Professional personnel carry out subject cataloguing and classification of monographies and articles in the academic libraries of Serbia. That staff combines its mother tongue with the professional terminology contributing to the enrichment of library users' vocabulary, particularly if we know that they retrieve the e-catalogues regularly. It is through using professional e-resources that libraries promote their own work as well as the work of every single student, researcher or professor who is also a library user. Libraries were in the very core of the Information Society and they will stay in it if they will keep tending to get closer to their users needs.

The digitization of library materials goes on in accordance with normative acts of the competent libraries. The process of digitization contributed to the opening of a new epoch for the academic libraries having in mind that they transform contents for the needs of users into another form making the process of learning more interactive, practical and more efficient as well. Such a progress stimulates every economic researcher to participate in the process of learning in order to develop his entrepreneurial knowledge and professional orientation. Except that, the academic librarianship is the entrepreneurial one if it keeps finding out new possibilities for attracting users, for including them into the social environment, in fact - into the Knowledge Society.
\end{abstract}

Keywords: education, entrepreneurship, academic librarianship, Serbia.

\section{INTRODUCTION}

$\mathrm{T}$ The management of an enterprise will estimate whether that organization needs new technology good enough for achieving higher financial result. The scopes of plan and development in an enterprise impose a way of solving technical problems. Management makes decisions in every enterprise. That same layer will make also decisions whether new

\footnotetext{
318 "Svetozar Marković” University Library, Bulevar kralja Aleksandra 71, 11000 Belgrade, Serbia
} 
equipment should be acquired. World market imposes the indispensability of reexamining technology regularly in order to achieve sustainable development.

The entrepreneurship includes in a way the ability to estimate working conditions in disruptive time. An enterprise keeps facing certain risks in its`environment. Therefore, the enterprise has to carry out its' own adjustments. If every enterprise would take care on its proper accumulation they would get easier to the situation of selecting optimum technology for its ' own activity in future. They would contribute in such a way to the economic development of the society which has to face unavoidably the obligations towards younger and older population.

State which is an entrepreneur since the age of New Deal will think much of its' own infrastructure in a contemporary way. Telecommunications become more and more important with an intensified expansion of information. It is due to the development of private universities, that certain higher quality of education is achieved particularly because the competition involves potential postgraduates into the process of selecting school for their further studies. The „Svetozar Markovićc University Library in Belgrade is the central library at The University of Belgrade whose tradition is long enough to insure high-quality education for its' students.

An enterprise is the basic cell of an economy. Gross domestic product per capita depends on the way it performs its` activity. GDP p.c. is one of the basic economic development indicators in every country. Its`value alters.

Economic information keeps concentrating in different data bases. Telecommunications are getting developed in such a way that multimedia means can be widely and intensively used for promotive purposes of libraries as cultural and educational institutions. Library 3.0 is a digital library. It includes the repositories with full texts of papers such as doctoral dissertations which can be even found in free access. In Europe it is in accordance with Berlin Declaration on Open Access to Knowledge in Sciences and Humanities (1).

„Svetozar Markovićc University Library in Belgrade gives necessary metadata and uploads doctoral dissertations defended in Belgrade (2). They are in free access (3). The University of Kragujevac has its' PHAIDRA (4). Except that, The University of Niš has also its' open repository PHAIDRA for the same or similar purpose (5). Therefore each of these three universities takes care of its' digital repository which contains freely available materials.

Cumulative e-catalogue COBIB.SR has a technical connection with digital repositories PHAIDRA (6). So, every user who would come across some bibliographic description of a doctoral dissertation he would like to read, may receive its' full text by clicking on a blue link e.g. perma-link. A doctoral dissertation in full text received in such a way can be downloaded.

\section{Library in the entrepreneurial world}

The entrepreneurial spirit improves the work of a library that a user has to contact for many reasons. Each academic library has a need for investing into its' own building, into the acquisition of new equipment, into the acquisition of book and non-book materials, into maintaining its`own installations. Except that, there is undoubtedly a need to invest into the intellectual capital. The professional development of the employed is extremely important for every marketing oriented library which keeps following technical and scientific progress in real and an e-environment. 
It is due to the tables 1 and 2 that the following is to be noticed: there are lot of materials on marketing, trade, finance and banking in the academic librarianship of Serbia. There were 3.759 bibliographic descriptions received through the retrieval of the cumulative e-catalogue COBIB.SR for a key word ,entrepreneurship“ typed out in Serbian. However, it is for the same key word that only 685 references were found in the local data base of the „Svetozar Marković“ University Library. The retrieval was realized in October 2018.

It should be mentioned that the cataloguing and classification of library materials in the academic librarianship of Serbia is being realized with book in hands e.g. de visu. Except that, the „Svetozar Marković“ University Library is of lending type. Its” work is partly public - not absolutely public. The nature of its work is combined: educational-scientific, partly cultural.

The academic libraries usually are not the public ones. Its' members are mostly those students who study at a faculty or an academy the library belongs to. Professors as well as researchers employed at the faculty or the academy are also among the members of that library.

The central library of the University of Belgrade e.g. the „Svetozar Marković“ University Library, open for users since 1926 is renewed in 2018. It was closed only several days. This fact tells us how important this institution is for the work of student and teaching population in Belgrade and Serbia as well. According to the statistical data for the academic year 2017/2018 in the Republic of Serbia, 256.172 students were inscribed to the studies of all the levels at faculties or the schools of the same rank. It is also known that $43,4 \%$ of the total number of the inscribed is of male gender and 56,6\% are of female gender. Except that $86,8 \%$ of students are inscribed to state universities and $13,2 \%$ to private ones. According to the way of financing studies, $41 \%$ or 104.909 students were inscribed to state budget and $59 \%$ are self-financing (7).

Table 1. Bibliographic descriptions for works in the domain of entrepreneurship in the ecatalogue of the "Svetozar Markovic" University Library in Belgrade - accessed 4th October 2018. (All materials; all languages)

\begin{tabular}{|l|r|}
\hline Banking & 2.014 \\
\hline Budget & 388 \\
\hline Business finance & 268 \\
\hline Capital & 2.014 \\
\hline Costs & 516 \\
\hline Economic development & 2.540 \\
\hline Entrepreneurship & 685 \\
\hline Finance & 3.560 \\
\hline Foreign trade & 197 \\
\hline Investments & 649 \\
\hline Marketing & 2.329 \\
\hline Organization of enterprise & 910 \\
\hline Planning of enterprise & 144 \\
\hline Prices & 227 \\
\hline Trade & 3.507 \\
\hline
\end{tabular}

So, having in mind the data from the tables 1 and 2 it can be noticed that the academic librarianship of Serbia has useful materials in its 'own offer for those students, researchers, professors, who are interested in entrepreneurship. Except that, the academic librarianship of Serbia has free access to the e-journals with articles in full text. The „Svetozar Marković“ 
University Library gives also the services of an interlibrary loan service with abroad. It is in such a way that the lack of necessary literature can be partly compensated for.

Although we live in the Knowledge Society which is an Open Society as well, there are less works in free access than library users would like to find. Those authors who give a consent for their papers to be published in free access are the promoters of science.

Table 2. Bibliographic descriptions in the domain of entrepreneurship in the cumulative ecatalogue COBIB.SR accessed 4th October 2018. (All materials; all languages)

\begin{tabular}{|l|r|}
\hline Banking & 26.510 \\
\hline Budget & 4.391 \\
\hline Business finance & 1.918 \\
\hline Capital & 15.792 \\
\hline Costs & 3.882 \\
\hline Economic development & 425 \\
\hline Entrepreneurship & 3.752 \\
\hline Finance & 28.931 \\
\hline Foreign trade & 2.126 \\
\hline Investments & 6.414 \\
\hline Marketing & 20.223 \\
\hline Organization of enterprise & 8.545 \\
\hline Planning of enterprise & 934 \\
\hline Prices & 2.542 \\
\hline Trade & 36.251 \\
\hline
\end{tabular}

On the other side, printed form is more expensive but eternal. It is less practical because of the necessity to photocopy the materials which requires additional expenditures. It is a financial burden for users. Talking from empirical point of view, such expenditures are high not just for those students who finished secondary school in Serbia but also for foreign students who enrolled at their studies in Belgrade. They share the destiny of local students.

The case of a library user who has a pocket drive is usual. However, students, researchers and many other professionals prefer to send materials to an email address particularly after the retrieval of e-journals. In that case even a pocket memory is not so indispensable.

Yuko Harayama discussed the situation in Japan during a meeting of researchers from Germany and Japan in July 2018. The meeting took place in Germany, at Ruhr-Universität Bochum. As Harayama claimed:

"...Japan is currently half way through the Fifth Science and Technology Basic Plan (2016-20), which seeks to develop a "super smart society" - or 'Society 5.0', a concept introduced by the Japanese government and its Council for Science, Technology and Innovation, under which various 21 st century challenges are addressed: the ageing population, climate change, food security, the limited availability of natural resources and the fulfillment of the 2030 Agenda for Sustainable Development" (8).

The Bologna Process implies a series of meetings and agreements between European countries to ensure comparability in the standards and quality of higher-education qualifications. That would contribute to an easier migration of the intellectual capital inside Europe. Having in mind all these tendencies The "Svetozar Marković" University Library performs its' activities in 
accordance with educational plans and programs of the universities in Serbia. However it also keeps acquiring foreign editions mostly through the process of exchange which is being carried out with more than 100 countries worldwide.

Chart 1. The number of bibliographic descriptions on entrepreneurship, marketing and investments in English in the e-catalogue of The „Svetozar Marković“6 University Library in Belgrade

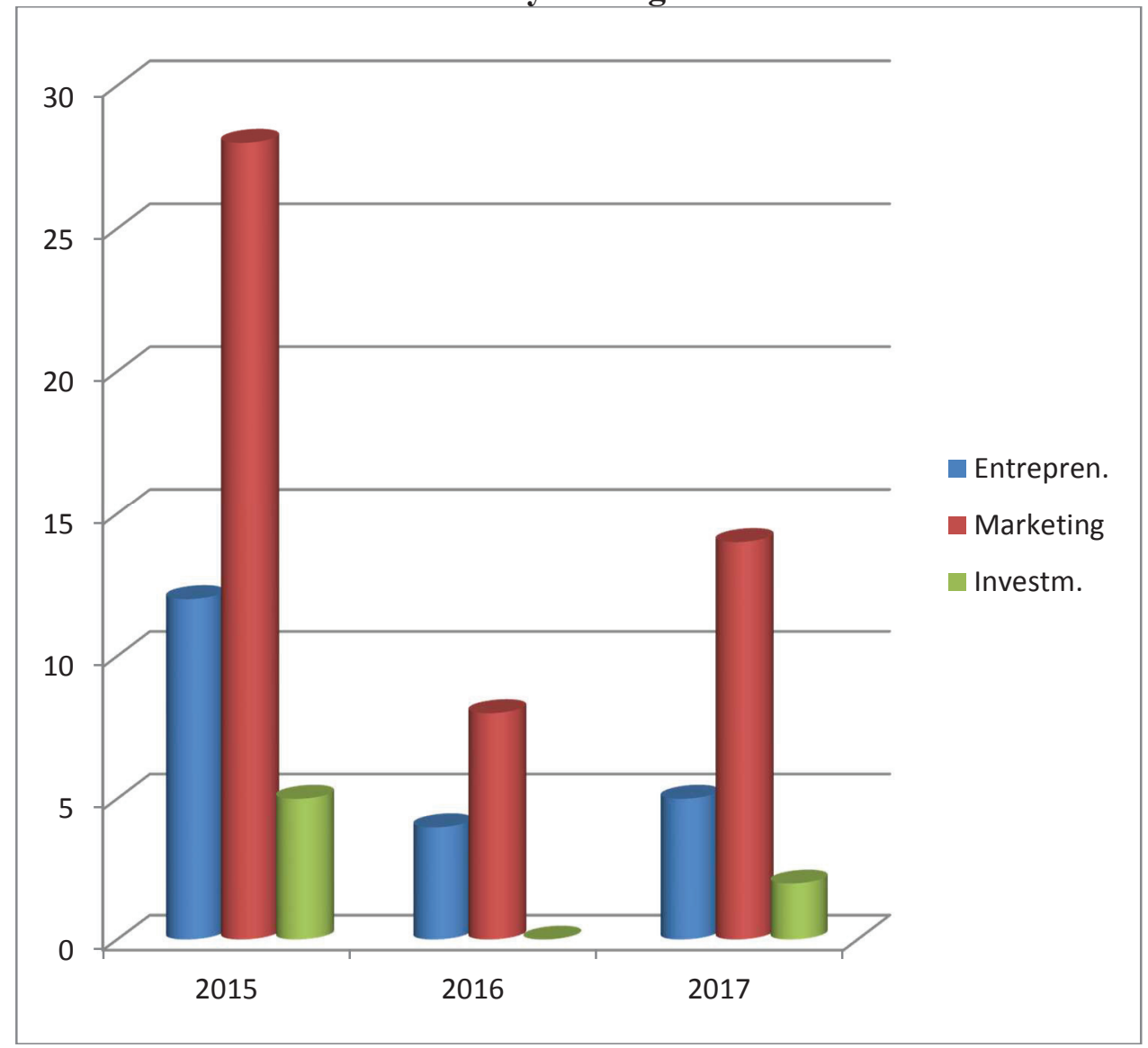

(Access to the e-catalogue: 4th October 2018.)

If we have in mind that the central library of the University of Belgrade acquires literature in foreign languages also, it would be meaningful to have a look at the chart no. 1. According to this illustration, it is obvious that the complete materials in the University Library, on entrepreneurship, marketing, and investments were covered. This chart show that the majority of bibliographic descriptions and materials in English are on marketing during the period 20152017.

Let us see to the linguistic structure of the materials on marketing: as far as the materials in foreign languages are concerned, it can be noticed that the majority of literature in the collections of the central library of the University of Belgrade is in English, e.g. even $86 \%$ of references. Therefore it can be noticed also that $11,30 \%$ of library units are in Croatian. The rest of materials are in other languages. Such a situation is illustrated by the chart no. 2 which is in the form of a structural graph. 


\section{Chart 2. Bibliographic descriptions of works on marketing in the collections of the "Svetozar Marković" University Library in Belgrade (only materials in foreign languages)}

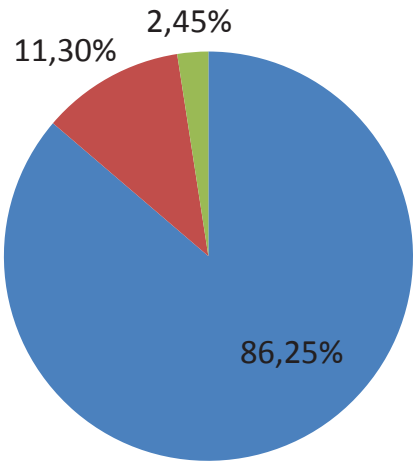

Nowadays Cooperative On-line Bibliographic System \& Services (COBISS) is being implemented in Slovenia, Serbia, at Kosovo and Metohia, in Bosnia and Herzegovina, in Montenegro, and Macedonia. Except that, COBISS is also being implemented in Albania and Bulgaria (9). The states of ex-Yugoslavia where COBISS is being implemented are colored in green on the picture 1 .

Picture 1. COBISS in the states of ex-Yugoslavia

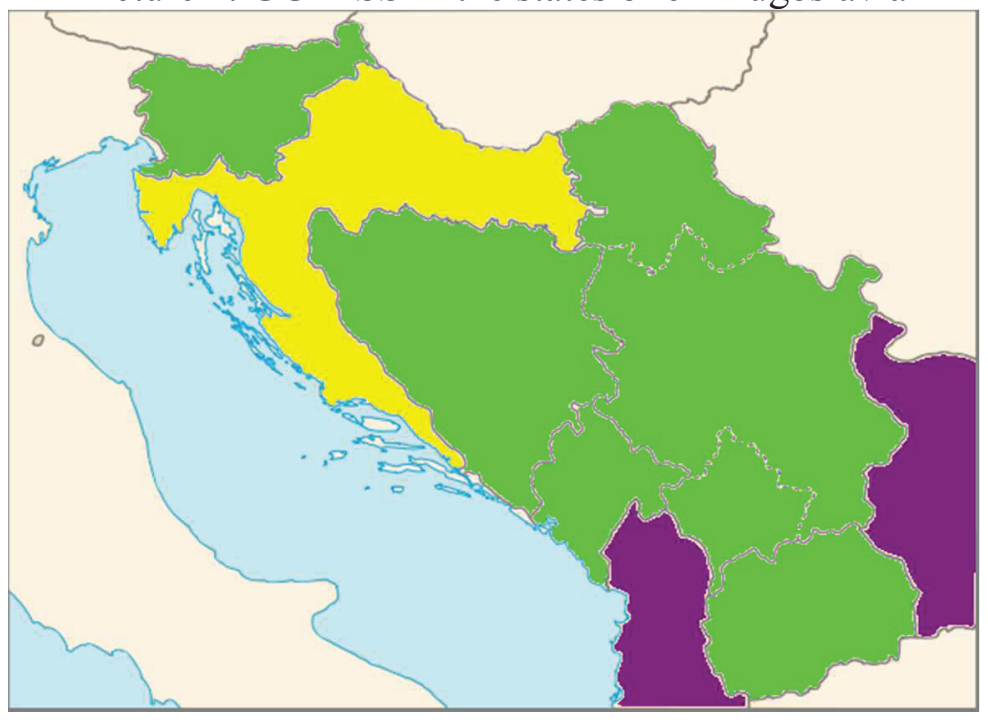

It is by the retrieval of the European Portal of e-theses DART that we can notice the following: the vast majority of doctoral dissertations which contain the term entrepreneurship as a key term are defended in France - even 465 theses. Little less is defended in the United Kingdom 456. As far as the Netherlands is concerned, for example, there are 256 theses defended which is also a high number (10). 
Table 3. The number of e-theses for the key word entrepreneurship on The European Portal of E-theses DART

\begin{tabular}{|l|r|}
\hline State & No. of e-theses \\
\hline France & 465 \\
\hline United Kingdom & 456 \\
\hline Netherlands & 256 \\
\hline Sweden & 254 \\
\hline Finland & 122 \\
\hline Italy & 121 \\
\hline Spain & 112 \\
\hline Germany & 104 \\
\hline Ireland & 68 \\
\hline Belgium & 48 \\
\hline Greece & 31 \\
\hline Switzerland & 31 \\
\hline Norway & 30 \\
\hline Hungary & 21 \\
\hline Czech Republic & 17 \\
\hline Denmark & 17 \\
\hline Serbia & 17 \\
\hline Portugal & 16 \\
\hline Estonia & 13 \\
\hline Croatia & 11 \\
\hline Latvia & 10 \\
\hline Poland & 7 \\
\hline Slovenia & 6 \\
\hline Austria & 5 \\
\hline Lithuania & 3 \\
\hline Bulgaria & 2 \\
\hline &
\end{tabular}

Source: www.dart-europe.eu (Accessed 5th October 2018.)

It would be interesting to have a look at the situation in the countries of Ex-Yugoslavia. We may rely also on the table 3. According to it, 17 doctoral dissertations are defended in Serbia. It is the same case in Czech Republic and Denmark (17 e-theses). In Croatia 11 theses where the term entrepreneurship is a key one are defended. In Slovenia, 6 theses are defended and in Austria only five theses. This paper doesn 't comment the quality of these materials which are freely available.

\section{Conclusion}

The materials which are included into the offer of Serbian academic librarianship consist of books, articles, doctoral dissertations and other resources. The academic librarianship of Serbia processes the materials in entrepreneurship mostly in Serbian and in English, less in other languages. The central university library of The University of Belgrade is of lending type.

The University of Belgrade, The University of Kragujevac and The University of Niš have, each of them, an open digital repository - PHAIDRA (Permanent Hosting, Archiving and Indexing of Digital Resources and Assets). Full texts of doctoral dissertations are downloaded into it. These doctoral dissertations are mostly in free access. 
The „Svetozar Marković“ University Library, for example, has an interlibrary loan service with abroad. It is a way the lack of literature is to be partly compensated for. The European Portal of e-theses DART offers full texts from different professional fields including economics and entrepreneurship.

\section{References}

[1] Berlinska deklaracija o otvorenom pristupu naučnom znanju, http://www.bg.ac.rs/files/sr/nauka/Berlinska_deklaracija.pdf (Accessed: 23.11.2019.)

[2] The "Svetozar Marković" University Library, http://www.unilib.rs (Accessed: October 2018)

[3] E-theses of The University of Belgrade, http://eteze.bg.ac.rs (Accessed: October 2018)

[4] E-theses of The University of Kragujevac, http://eteze.kg.ac.rs (Accessed: October 2018)

[5] E-theses of The University of Niš, http://eteze.ni.ac.rs (Accessed: October 2018)

[6] National Library of Serbia, https://www.nb.rs (Accessed: October 2018)

[7] Republički zavod za statistiku Srbije, http://www.stat.gov.rs/sr-latn/vesti/20180629upisani-studenti-u-\%C5\%A1kolskoj-201718-godini/?s=1104 (Accessed: October 2018)

[8] World university news, Silvia Richter, Japan : Universities must step up to cater for "Society 5.0" , University, World News, 13 July 2018, issue no. 514. http://www.universityworldnews.com/article.php?story=20180711171755220 (Accessed: October 2018)

[9] Institut informacijskih znanosti u Mariboru, http://www.izum.si (Accessed: October 2018)

[10] European Portal of E-theses DART, http://www.dart-europe.eu (Accessed: October 2018) 